\title{
Citizen Participation and Network Governance of Regional Water Resources in China
}

\author{
Jie Ma \\ University of Electronic Science and Technology of \\ China \\ Chengdu, Sichuan, P.R. China, 611731 \\ Majie2436@126.com
}

\author{
Liming Suo \\ University of Electronic Science and Technology of \\ China \\ Chengdu, Sichuan, P.R. China, 611731 \\ dinastysuo@126.com
}

\begin{abstract}
The double failure of the local government and the market exist in the regional resources governance of our country. Water resources governance with citizen participation is restrained by awareness, motivation and capacity while multidimensional properties such as economy, society and ecology of water resources determine the necessity of multiple participations in water resource. Citizens as the main body role in participation in governance should be concerned, the paper put forward the citizen participation network governance and hierarchy which is based on individual, organization and across regions. On the basis, combining with the model of network governance, innovation model construction and implement path of our county citizen participation in water resources network management are proposed, including the introduction of informal organization and informal authority involvement, to adjust the incentive structure of local government and innovate to the local citizen participation system.
\end{abstract}

Keywords-citizen participation; area; water resources; network governance

\section{INTRODUCTION}

In 2012, "the China's sustainable development strategy report" pointed out that in the 30-year reform and opening up, China's GDP increased by 15 times, and the energy consumption has increased by nearly 4 times, the main resource consumption per unit of GDP and the pollutant emission is much higher than developed countries, resources environmental carrying capacity has been unable to meet the requirements of economic development. Facing with serious situations of resource constraints tightening, serious environmental pollution and ecological degradation, the vital interests of every citizen come to water. However, the present water resources vertical management system is difficult to effectively save water resources and protect water environment.

One of the consensus reached in 2002 world summit for sustainable development as the same as one of the basic principles of water resources management is that the water resources development and management should be based on extensive public participation, including different level of water user, interest groups, planning, policy making and managers involvement(Hooper B. 2005). Our country has carried out extensive theoretical and practical researches of public participation in water resources management. With the environmental legislation and the system construction about social participation in water conservancy in the central file no. 1 of 2011, scholars generally aware of the importance of public participation in water resources management and discussed from the necessity of public participation in water resources management, the participation fields, guarantee and ways. The framework of the paper is based on the analysis of system and governance, emphatically from the multiple attributes of water resources, discusses the structure of public participation and its realization ways.

\section{CONSTRAINTS OF CITIZEN PARTICIPATION IN WATER RESOURCES}

First, confirm that you have the correct template for your paper size. This template has been tailored for output on the US-letter paper size. If you are using A4-sized paper, please close this file and download the file for "MSW_A4_format".

The template is used to format your paper and style the text. All margins, column widths, line spaces, and text fonts are prescribed; please do not alter them. You may note peculiarities. For example, the head margin in this template measures proportionately more than is customary. This measurement and others are deliberate, using specifications that anticipate your paper as one part of the entire proceedings, and not as an independent document. Please do not revise any of the current designations.

\section{A. Citizen Participation}

How to make public participation play correctly and effectively? As an interest coordination mechanism under the circumstance of the intervention of social stratification, public diversified needs and interest groups, public participation emphasizes the citizen's functions of participation, decision and management in public affairs management(Boyer, 2004). After 50-year practice in environmental protection, resource management, ecological construction and other fields, a relatively mature theory system has formed (Berry JK.2000; ZhangLicheng, WangHong, WangLushang, etal 2005).

The power structure relationship between managers and the persons who are managed in public participation transforms from top-down decision-making management to integrated mode of decision-making and management considering citizens' democratic rights and interests. The rights relations change comes from the clash and harmonic 
of the reality revisionism and citizens egalitarian, by representative democracy toward participation in democracy, namely, public influence the decision making and management that related to its own interests through direct or indirect different levels of participation, rather than via the traditional electoral client to play a role of participation. Participation in democracy has direct positive influence on the decision making process, and representative democracy only has indirect influence (Aidt. T S, Jayasri D, Elena L. 2006).

\section{B. The Plights of Citizen Participation}

Multiple agents based on public participation in water resources governance structure is superior to the original single vertical structure, however, in reality, various obstacles make water management with public participation difficult to carry on effectively.

First of all, insufficient understanding in ideology of water resources governance exists in our country citizen participation. BiXia etc.(2010)argue that China's political culture's influence on the political participation behavior is decisive. Traditional ideas of rankings inhibit the improvement of the public participation, and group psychology prevails to free-riding behavior. At the same time, the citizen participation ability is insufficient. In 2008, "the public environmental protection index", guided by the environmental protection administration and formatted and published by the China environmental culture promotion association, shows only $16 \%$ of the public knows the free informants' hot-line telephone of environmental problems, with only $9.2 \%$ of them dialed it. The public lack of necessary knowledge about environmental protection which makes them can't find the institutionalization and rational way to express their interest demand when facing specific environmental problems.

Second, non-clear participation rights suppress their motivation to participate in water resource management. Because our country of citizens' rights to use, to know, to participate in water resource and environment do not clearly be defined in law, citizens are hard to find the right system security tools for participation in water recourses management. Especially the non-clear definition of citizens' environmental right makes it hard for citizens to measure their rights if destroyed, and the loss ascription problem, lack of the system guarantee of the citizen participation makes the insufficient steam of the participation.

Third, the citizens to participate in the governance of water resources affected by rational choice. One is the possibility of a free-rider. Even if the citizen has the definite environmental right, but as for citizens, the natural environment and resource management is a public product, its earnings have stronger positive externalities, so citizens may wait for other citizens to participate in, enjoy the results of them. Two is the cost of collective action. Even if citizens do not choose a lift, but individual citizens to participate in is hard to work. Collective action should be the basis, but its higher cost makes it a kind of transaction cost. According to the Coase Theorem's point of view, as the existence of transaction cost, the public resource governance structure changes, when citizens organization costs outweigh the possible potential earnings, the collective action momentum will be inhibited. The last one is the insufficient knowledge and information. For citizens, even common understanding is solved, the problem of common knowledge cannot effectively be solved. Common knowledge, that is, citizens can effectively observe the status quo of water resources and master the knowledge of its governance. Under the premise, new coordination costs will not create after collective action. However, because of its macroscopic and microscopic nature, water resources information will generate common knowledge on the premise of transparent after sharing process. Although water resources is becoming paid more and more attention, but the public even the administrative departments do not mater sufficient knowledge and information about water resources. No matter the public, administrative departments or authority, they have no a unified access, means and platform to get water resources information. The barrier results in the information gap between stakeholders, affect the recognition degree of the same event. The gap not only reduces the efficiency of transboundary water resources conflict management, but more become a fundamental obstacle in citizen participation of water management.

\section{LEVEL OF CITIZEN PARTICIPATION}

\section{A. Network Governance}

Although the study of network governance has gone through nearly 20years, most scholars agree that there is no general theory of network governance (Kilduff and Tsai, 2006; Galaskiewicz, 2007; Keith g. Provan and Amy Fish, 2007), the research level and content depends on the research goal. Table 1 summarizes the definition of network governance of the representative scholars. These definitions emphasize the cooperation pluralism and polytonality between interest agentss, and analyze with longitudinal or transverse characterized by network structure.

Water resources network governance model with citizen participation involves multiple individuals, sectors, and multiple geographical areas, and characterized by decision environment complexity, diversification of decision-making, the blurred boundaries of decision-making agentss, etc. To simplified the problem, the narrow sense network concept defined by Keith G. Provan(2007) is used: network is a governance structure built by three or more legal nature organizations, and the groups work together not only achieve personal goal, but at the same time to achieve the common goal of the network level. So network governance is a kind of cooperation mechanism, is a way of governance. It is a goal oriented network governance mechanism (Kilduff and Tsai, 2003). In public sector and non-profit organizations which need to take collective action to solve complex problems, this kind of network governance mechanism is particularly important (Provan and Milward, 19951 Teisman and Klijn, 2002; Agranoff and McGuire, 2003; Provan, Isett and Milward, 2003; Imperial, 2005). Objective orientation of network governance shows that participants are only responsible for network level of target, and voluntary to 
follow the governance rules and procedures, rather than the interests or power.

TABLE I. The DEFINITIONS OF NETWORK GOVERNANCE

\begin{tabular}{|c|c|}
\hline author & definition \\
\hline Scharpf and O'Toole & $\begin{array}{l}\text { Network management is to reconstruct the } \\
\text { network relationship, mobilize the collective } \\
\text { action, reach horizontal multilateral coordination }\end{array}$ \\
\hline $\begin{array}{l}\text { Bruijn and } \\
\text { Heuvelhof }\end{array}$ & $\begin{array}{l}\text { Network governance is a goal-oriented problem- } \\
\text { solving tool }\end{array}$ \\
\hline Klijn & $\begin{array}{l}\text { Defined as the use and change of network rules } \\
\text { and resources from the perspective of game to } \\
\text { start a new game or influence the course of the } \\
\text { current game }\end{array}$ \\
\hline $\begin{array}{l}\text { Agranoff and } \\
\text { McGuire }\end{array}$ & $\begin{array}{l}\text { Is managing the elastic structure of the collective } \\
\text { efficiency. The controller must have the ability, } \\
\text { technology and knowledge that different from } \\
\text { single organization }\end{array}$ \\
\hline $\begin{array}{l}\text { R.Karl and } \\
\text { Rethemeyer }\end{array}$ & $\begin{array}{l}\text { Three kinds of model: political management, } \\
\text { cooperation management and governance. } \\
\text { Network governance is to use the "material- } \\
\text { system" resources and social structure resources }\end{array}$ \\
\hline Keith G. Provan & $\begin{array}{l}\text { Structure relationship made by various natural } \\
\text { organizations that have special resources. This } \\
\text { structure is a means of governance mechanism } \\
\text { than can make special resources play a biggest } \\
\text { role }\end{array}$ \\
\hline
\end{tabular}

\section{B. Water resources network governance hierarchical structure}

This paper argues that water is kind of quasi public goods, the stakeholders involved in for-profit and non-profit sector, private and public sector, NGO and other organizations and individuals. However in the multiple main body, the lowest participation rate is citizens, barriers to participation is also the biggest. Citizens participation is not just the individual citizens, but includes three levels of individuals, organizations and across regions. Based on this, according the water resources properties, the framework of three levels that water resources network management with public participation is defined.

The first level is the individual level. Single water user gains economic benefits and personal utility from the use of water resources. Behavior agents represented by the private sector pursues the economic profit maximization or individual utility maximization, thus it shows the economic attribute of water resources. And the relationship between stakeholders and water resources is economic and trade relationship on the basis of market. At this level, when water resources conflict, the gain and loss between different agentss can be determined and therefore economic means can be used (such as compensation, the water rights trading, etc.).

The second level is organization. When the reason causing the conflict of water resources is only a single, non- economic factor, this level of governance may be took, namely cooperation between different civil organizations and the public sectors. At this level, different civil organizations and the public sector form unified coordination target and means of governance. A single solution is the goal of collaboration. The criterion of governance efficiency can be the time to solve problem and economic cost, also can measure economic and non-economic means such as social fairness, economic losses, pollution reduce and ecological compensation, etc.

The third level is across the regional level. Functional attributes of water resources is not only limited to the factors of production, but more important to maintain ecological function and sustainability of human and nature. It has ecological attribute. Wilde conflict and cooperation opportunities are implicit in water sharing. Network governance do not achieved limited in individual and organizational level, also need economic system, social system and ecological system, etc. that formed by across regions; meanwhile, to ensure the sustainability, the stakeholders of different generations relate due to water resources. At this level, it is hard to paint the connection between different stakeholders and water resources with a single relationship, and also cannot judge the size of the connection. When water resources conflict of different administrative areas involves multidimensional attributes and multiple main body, it needs to transit to network governance mode. Network management may be a single dimension of cooperation platform; however, the target and approach of public-private partnerships and network governance comprehensively promote and strengthen in the process of network governance (such as " $9+2$ " cooperation zone).

It can be integrated based on the analysis above that the haploid government management will fail owing to the multidimensional water resources. The problem of national system makes the individual citizens participation in water resource management difficult to achieve. As a consequence, the network management of water resources is the basic idea of network citizen participation.In view of the analysis on citizen participation, there are three part of the structure for the citizen participating in the water resources network framework (showed by diagram 1 ).

The first thing to be mentioned is the level choice of the citizen participation. The water resource is not only multidimensional, but also has multiplicity function. Not all water resources management fits all gradation. The level which the citizen has participated is decided by the multidimensional quality. The citizen needs to make a choice among the individual level, organizational level and cross-region level, which depends on the quality of water resources and the conflict that might be triggered by individual conflict, public conflict or regional conflict.

The second one is the selective organization of citizen participation. There are four features make the influence on the selective organization in the citizen participation. First one is about the rational consideration of selection; in the second part of this paper have already stated that the citizen participation got impact on the rational consideration, which is the outer behavior switch into the inner behavior changed 
by the personal benefit-cost rates under the designed system. The second should be the consideration of the organization's cost; citizen could get benefits by the participation, but the organization needs cost on coordination and inspiration. The key character in the selection of organization is the difference of degree of the enclosing, which have direct impact on the citizens' selection about the organization. The third one is about the consistency of goals. The consistency could impact on the citizen participation organizations' frame and size, because of the participants got different goals. The coordination and communication is the method of the consistency in the network, in order to get common cognition and value. The last dimension is the common knowledge and information; it could decrease the cost in the citizen participation in management and organizations' communication. But it is dangerous that the common knowledge and information runoff, large mount of money was need under the less motivation in the inner organization; otherwise, the network management should fail by the huge cost.

The third is the selective goal of citizen participation. The goal of network is the result of the procedure that the entire network's bodies forming the network. The multidimensional characteristic, shown like multi-goal selective, is the basic feature of citizen participation in the water resources governances. The difference of the water resources' governance in net-like citizen participation management and vertical government-lead management is the integrated ability of the goals; it is much more emphasis on the multi-goal participation in the citizen participation in water resources governance. In the citizen participation, the main method of the goals forming procedure is equal communication; the citizens' goal comes from the organization's network integration, the organization's goal comes from the coordination. As the audience of the water resources governance, citizen could enjoy the private benefit from the public resources, but also made the personal contributions to the public goal. For the communication method, it is more important in emphasis on the equality, but not the coordination of benefits in bodies. At this time, the goal of the network should be dynamic and continuous; the selective of the networks goal should be under the full consideration of the preference of accumulation of social capital and the equal o demands of the generation. Thus, the goal of citizen participation is fair, dynamic, heritage and continuous.

\section{ACKNOWLEDGMENT}

This paper is supported by Nation Science Funding(71003013); "Fundamental Research Funds for the Central Universities"'(ZYGX2010X024)

\section{REFERENCES}

[1] Hooper B. Integrated River Basin Governance, Learning From International Experience London: IWA publishing, 2005:1-18, 25-149, 165-276)

[2] MaJie, SuoLiming, The multidimensional attribute of water resources and the network governance patterns of cross-border water resources conflict in our country, Administrative management of China, 2010(4)a(in Chinese).

[3] MaJie, SuoLiming, Network governance model innovation of regional water resources sharing conflict, 2010(4)b(in Chinese).

[4] ZhouLi'an The tournament model research of China's local officials promotion [J], Journal of economic research, 2007( 7)(in Chinese).

[5] Lazear, E. , an d S. Rosen, / Rank -Order Tournament s as Optimum Lab or Contracts 0, Journal of Political Economy , 1981, 89( 5) , 841

[6] BoyerD. Planning for transportation equity in a diverse community [D]. Massachusetts: University of Massachusetts Lowel,2004.

[7] Berry JK. Form Paradigm to Practice: Public Involvement Strategies for Americas' Forests .Candidacy: Yale Schoo, 12000.

[8] ZhangLicheng, WangHong, WangLushang,etal. Social capital and farmer's willingness-to-join a newly established community-based health insurance in rural China.Health Policy,2005, 6:1-9.

[9] Aidt. T S, Jayasri D, Elena L. Democracy comes to Europe: Franchise extension and fiscal outcomes 1830-1938.European Economic Review, 2006, 50: 249-283.

[10] PROVAN K, KENIS P. Modes of Network Governance:Structure, Management, and Effectiveness. Journal Administration Research and Theory,2008,18 (2):229-252.

[11] KILDUFF M,TSAI W,HANKE R. A aradigm oo ar? A ynamic tability consideration of the social network esearch program. Academy of Management Journal,2006,31 (4):1031-1048.

[12] GALASKIEWICZ J. Has network theory of organizational behavior ived $\mathrm{p}$ to ts promises?. Management and Organization Review,2007,3 (3):1-18.

[13] KEITH G P,AMY F. Interorganizational Networks at the Network Level:A Review of the Empirical Literature on Whole Networks . Journal of Management,2007,33(4):1011 -1076.

[14] KILDUFF M,TSAI W. Social Networks and Organizations .Thousand Oaks,CA:Sage Press,2003.

[15] PROVAN K G,MILWARD H B. A preliminary theory of network effectiveness:A comparative study of our community mental health systems . Administrative Science Quarterly,1995,40 (2):1-33. 